\title{
Online Assessment of Islamic Religious Education Learning
}

\author{
Received: 13-12-2021 \\ Revised: 08-01-2022 \\ Accepted: 26-01-2022
}

\begin{abstract}
Abdul Aziz' Reem Abou-Samra ${ }^{2}$ Andika Aprilianto ${ }^{3}$
Fakultas Tarbiyah, Institut Pesantren Kh. Abdul Chalim Pacet Mojokerto, Indonesia ${ }^{1-3}$

Roeper School for Gifted Education in Birmingham, Michigan, Unites States ${ }^{2}$

Email: Doelazis45@gmail.com, reem.abou@gmail.com
\end{abstract}

\begin{tabular}{l}
\hline Keywords: \\
Implementation, \\
Online assessment, \\
Assessment \\
planning, \\
Assessment \\
implementation, \\
Islamic Religious \\
Education \\
\hline
\end{tabular}

\begin{tabular}{l} 
Kata kunci: \\
Implementasi, \\
Penilaian online, \\
Perencanaan \\
Penilaian, \\
Pelaksanaan \\
Penilaian. \\
Pendidikan Agama \\
Islam. \\
\hline
\end{tabular}

\begin{abstract}
This article describes the planning and implementation of onlinebased exam evaluations in Islamic Religious Education Learning at the Nahdlatul Ulama 05 Brangsong High School. This article uses qualitative research with a case study approach. For data collection, researchers used observation, interviews, and documentation techniques. The results of this article are Planning for online-based assessment evaluation in Islamic Religious Education learning at SMA NU 05 Brangsong, (1) Planning in general (a) Preparation of school work programs, (b) Formation of an exam committee, (c) Preparing equipment both hardware and software. (2) Planning specifically, namely by (a) determining goals, (b) identifying student abilities, (c) compiling question grids and question cards, (d) making questions, (e) evaluation and analysis, (f) revision and creating new questions. Implementation of online-based exam evaluation in Islamic Religious Education learning at SMA NU 05 Brangsong, (1) implementation of pre-exams (2) Preparation and preparation of test schedules, (3) Division of test rooms, (4) Installing applications. Implementation of the assessment, (5) fill in the username and password, (6) do the questions, (7) end the test.

\begin{tabular}{l} 
Abstrak \\
\hline Artikel ini bertujuan untuk mendeskripsikan perencanaan dan implementasi \\
evaluasi ujian berbasis online pada Pembelajaran Pendidikan Agama Islam \\
di Sekolah Menengah Atas Nahdlatul Ulama 05 Brangsong. Artikel ini \\
menggunakan jenis penelitian kualititatif dengan pendekatan studi kasus. \\
Untuk pengumpulan data peneliti menggunakan teknik observasi, \\
wawancara dan dokumentasi. Hasil artikel ini adalah: Perencanaan penilaian \\
online pada pembelajaran Pendidikan Agama Islam di SMA NU 05 \\
Brangsong, (1) Perencanaan secara umum (a) Penyusunan progam kerja \\
sekolah, (b) Pembentukan panitia ujian, (c) Menyiapkan peralatan baik \\
hardware maupun software. (2) Perencanaan secara khusus yaitu dengan (a) \\
Menentukan tujuan, (b) Mengidentifikasi kemampuan siswa, (c) Menyusun \\
kisi-kisi soal dan kartu soalnya, (d) pembuatan soal, (e) evaluasi dan analisis, \\
(f) Revisi dan pembuatan soal baru. Pelaksanaan penilaian online pada \\
pembelajaran Pendidikan Agama Islam di SMA NU 05 Brangsong, (1) \\
pelaksanaan pra-ujian (2) Pembuatan dan penyusunan jadwal tes, (3) \\
\hline
\end{tabular}
\end{abstract}

http://pasca.jurnalikhac.ac.id/index.php/tijie/index 
Pembagian ruang tes, (4) Menginstal aplikasi. Pelaksanaan ujian, (5) mengisi username dan pasword, (6) mengerjakan soal, (7) mengakhiri tes.

\section{INTRODUCTION}

Conventional paper exams are the form of assessment carried out for Islamic Education; in which the process of making questions, processing, and assessing uses paper. ${ }^{1}$ Traditional exams that use form still have many obstacles and problems, making the exam process ineffective and inefficient. ${ }^{2}$ The test used as a benchmark for assessment by the teacher has not been able to represent all the students' abilities, where the validity of the exam itself is reduced. ${ }^{3}$

Some of the problems that arise in implementing conventional exams include costs, time, and human resources. In terms of expenses, conventional exams require relatively high prices. Educational institutions must prepare question documents, answer sheets, and other related documents printed and then copied. ${ }^{4}$ Conventional exams take a rather long time because they have to go through several processes from printing, duplicating, distributing, implementing, and reaching the stage of manual correction of answers, which takes time. ${ }^{5}$ Therefore, students have to wait for several days or even weeks to find out the exam results. In terms of human resources, it requires more personnel, so it also requires longer cooperation and coordination.

Cheating is also one of the problems that arise in the implementation of conventional exams. In addition, an affair also occurred before the exam implementation process, where there was a leak of questions. Even schools and teachers deliberately leak questions so that their students have high scores and are

\footnotetext{
${ }^{1}$ Diah Arum Kartikasari, 'Pemahaman Matematika: Penerapan Model Arcs Dan Penilaian Kinerja', Jurnal Evaluasi Pendidikan 9, no. 1 (30 March 2018): 6-15, https://doi.org/10.21009/JEP.091.02.

${ }^{2}$ Darryl Alexander Braier-Lorimer and Hannah Warren-Miell, 'A Peer-Led Mock OSCE Improves Student Confidence for Summative OSCE Assessments in a Traditional Medical Course', Medical Teacher 0, no. 0 (25 November 2021): 1-6, https:/ / doi.org/10.1080/0142159X.2021.2004306.

${ }^{3}$ Heri Retnawati, Teori Respon Butir Dan Penerapannya: Untuk Peneliti, Praktisi, Pengukuran Dan Pengujian, Mahasiswa Pascasarjana (Yogyakarta: Parama Publishing, 2014), 190.

4 Tatang Hidayat and Abas Asyafah, 'Konsep Dasar Evaluasi Dan Implikasinya Dalam Evaluasi Pembelajaran Pendidikan Agama Islam Di Sekolah', Al-Tadzkiyyah: Jurnal Pendidikan Islam 10, no. 1 (29 May 2019): 159-81, https://doi.org/10.24042/atjpi.v10i1.3729.

${ }^{5}$ Masood Fathi et al., 'Assembly Line Balancing Problem: A Comparative Evaluation of Heuristics and a Computational Assessment of Objectives', Journal of Modelling in Management 13, no. 2 (1 January 2018): 455-74, https:/ / doi.org/10.1108/JM2-03-2017-0027.
} 
still seen as good by the community. ${ }^{6}$ Not infrequently also during the exam implementation, there is a shortage of question scripts and answer sheets, so students have to wait to get a question script or answer sheet, which can be detrimental to students. ${ }^{7}$

From these problems, the assessment should be a tool to measure the extent to which students' ability is not able to represent the abilities of students. So that the validity of the test itself is reduced and educators cannot get maximum data about the level of success of the learning objectives set.

So far, the assessment still uses paper and is not integrated with the times. ${ }^{8}$ Assessment of Islamic Religious Education (IRE) learning is still conventional, namely by paper and oral practice. ${ }^{9}$ Although the government recommends authentic assessments that cover students' overall ability, the implementation stage has not been maximized and is old-fashioned. ${ }^{10}$ What makes it different from previous research is that this article describes the planning and implementation of online IRE learning assessments.

The online assessment applied at SMA NU 05 Brangsong is carried out in the classroom like an exam as usual. It's just that they don't use paper but cellphones or computers (software) that are connected using a computer network to connect the test application to students with the server. The implementation of the exam uses an application that has been designed in such a way so that it can be used both on mobile phones and computers. The test application uses a local network that has been designed and is connected to the server to manage the test execution process.

\footnotetext{
${ }^{6}$ Yohanes Adio Balan, Sudarmin, and Kustiono, ‘Pengembangan Model Computer Based Test (CBT) Berbasis Adobe Flash Untuk Sekolah Menengah Kejuruan', Innovative Journal of Curriculum and Educational Technology 6, no. 1 (2017): 37.

${ }^{7}$ Nur Nirmala Sagita and Amir Mahmud, 'Peran Self Regulated Learning Dalam Hubungan Motivasi Belajar, Prokrastinasi Dan Kecurangan Akademik', Economic Education Analysis Journal 8, no. 2 (12 July 2019): 516-32, https:// doi.org/10.15294/eeaj.v8i2.31482; Nurul Fadri and Muhammad Khafid, 'Peran Kecerdasan Spiritual Memoderasi Pengaruh Dimensi Fraud Diamond Dan Self-Efficacy Terhadap Kecurangan Akademik', Economic Education Analysis Journal 7, no. 2 (2018): 430-48.

${ }^{8}$ Hasan Baharun, 'Penilaian Berbasis Kelas Pada Pembelajaran Pendidikan Agama Islam Di Madrasah', MODELING: Jurnal Program Studi PGMI 3, no. 2 (18 September 2016): 204-16.

${ }^{9}$ Anis Marfuah and Febriza Febriza, 'Penilaian Autentik Pada Pembelajaran Pendidikan Agama Islam (PAI) Di Sekolah Dan Perguruan Tinggi', FONDATIA 3, no. 2 (30 September 2019): 35-58, https://doi.org/10.36088/fondatia.v3i2.301.

${ }^{10}$ Muzlikhatun Umami, 'Penilaian Autentik Pembelajaran Pendidikan Agama Islam Dan Budi Pekerti Dalam Kurikulum 2013', Jurnal Kependidikan 6, no. 2 (30 November 2018): 222-32, https://doi.org/10.24090/jk.v6i2.2259.
} 


\section{METHOD}

The research method used is qualitative research with a case study approach. The research location is in SMA NU 05 Brangsong, Kendal Regency, Central Java Province, from March 2021 to May 2021. The data collection technique uses participatory observation, interviews, and documentation. ${ }^{11}$ In contrast, the data analysis technique in the research that has been carried out is (1) Data reduction, namely reducing the data that has been obtained in the field both during interviews, observation, and documentation. (2) Display data, namely by describing the data that has been obtained in the field by categorizing and grouping. In this case, it is done by describing the planning and implementation of online-based evaluation (3) Drawing conclusions. In testing the validity of the data using triangulation techniques, discussions with friends, an extension of observations, using reference materials, conducting member checks, and auditing the research process.

\section{RESULT AND DISCUSSION}

\section{Online Assessment Planning on IRE Learning}

Planning is an important component in educational and learning evaluation activities, the initial step of the activity, and provides guidance and direction in action. Planning in the evaluation process will affect the effectiveness of the evaluation itself. ${ }^{12}$ So that in the implementation of the evaluation, a careful plan is prepared in advance. According to Zainal Arifin, evaluation planning must be carried out carefully, clearly, in detail, and comprehensively. ${ }^{13}$

Nahdlatul Ulama High School 05 Brangsong applying online assessment needs to use a proper plan to get maximum results. From the data that the researchers obtained, the online-based exam evaluation planning at the Nahdlatul Ulama 05 Brangsong High School, the researchers divided it into two, namely general planning

\footnotetext{
${ }^{11}$ Matthew B. Miles, A. Michael Huberman, and Johnny Saldana, Qualitative Data Analysis: A Methods Sourcebook (SAGE Publications, 2018); John W. Creswell, Qualitative Inquiry and Research Design: Choosing Among Five Approaches (SAGE Publications, 2012).

12 Rachel Pollitt, Caroline Cohrssen, and Wee Tiong Seah, 'Assessing Spatial Reasoning during Play: Educator Observations, Assessment and Curriculum Planning', Mathematics Education Research Journal 32, no. 2 (1 June 2020): 331-63, https://doi.org/10.1007/s13394-020-00337-8; Juanjo Galan, 'Towards A Relational Model for Emerging Urban Nature Concepts: A Practical Application and an External Assessment in Landscape Planning Education', Sustainability 12, no. 6 (January 2020): 2465, https://doi.org/10.3390/su12062465.

${ }^{13}$ Zainal Arifin, Evaluasi pembelajaran: prinsip, teknik, dan prosedur (Remaja Rosdakarya, 2009).
} 
and specific planning. In general, planning is carried out by the school and the implementing committee for the end-of-semester assessment, while Islamic education teachers themselves carry out planning.

The emergence of an online-based exam evaluation based on what was conveyed by Mr. Muh. Abdul Halim, SE, was the vice-chairman of the curriculum because he saw environmental conditions where the majority and almost all students now have cellphones. The assessment includes cell phones that were initially only used to play social media from the school used to learn. In addition, the evaluation of the online-based exam is also used to reduce paper as a form of caring for nature in reducing deforestation. ${ }^{14}$ For planning, the first is preparing a school work program at the beginning of the school year regarding assessment in preparation of this work program. Second, the formation of an examination committee as an implementation in preparation for the implementation of online-based exam evaluations. Third, prepare equipment, both hardware, and software, which are carried out by the exam administration committee, including creating exam question templates.

General planning on online assessment is a needs analysis, where a phenomenon occurs in students, and then the school sees the need for action in response to this phenomenon. Needs analysis is a process to find out the needs in solving a problem or phenomenon. Needs Analysis must be carried out before preparing an evaluation plan. ${ }^{15}$

Needs analysis is the tool used to take action at Nahdlatul Ulama 05 Brangsong High School. Information regarding smartphone use among students was obtained. The need for paper reduction was evaluated. These two needs were considered in making online-based exams for assessment

Planning specifically for online-based exam assessments at the Nahdlatul Ulama 05 Brangsong High School was carried out by the respective subject teachers; in this case, the researchers focused on the subjects of Islamic Religious Education. The planning carried out, in this case, was carried out by Islamic religious education

\footnotetext{
${ }^{14}$ Nur Aminudin and Irwan Susilo, 'Perancangan Sistem Aplikasi Ujian Online Berbasis Web Pada Sma Negeri 1 Kalirejo', Aisyah Journal Of Informatics and Electrical Engineering (A.J.I.E.E) 1, no. 1 (1 August 2019): 81-88, https://doi.org/10.30604/jti.v1i1.14.

15 Anita Budi Rahayu, 'Analisis Presrektif Guru Terhadap Kebutuhan Materi Reading Siswa Kelas XII Sekolah Menengah Kejuruan (SMK) Teknik Otomotif Untuk Menghadapi Ujian Nasional', Jurnal Riset Teknologi Dan Inovasi Pendidikan (Jartika) 4, no. 1 (5 May 2021): 195-202.
} 
teachers, namely compiling the online-based exam evaluation question instrument itself. The stages in the preparation are first, determine the purpose of the assessment, namely whether for daily tests, end of semester assessments, or other assessments. This goal is also to determine what type of assessment the teacher wants to carry out, whether formative, summative, or diagnostic. Second, identify the abilities of students.

Under what was conveyed by Mr. Mujahidin, S. Pd, namely 'indeed, from these tests the teacher can monitor the level of student knowledge, and the teacher's success in explaining the material in class.' ${ }^{16}$ The assessment can also be seen from the material that has been delivered or the results of previous assessments. Third, compose grids and question cards. This arrangement makes it easier for teachers to arrange questions as a form of test equipment. Fourth, making questions from a grid that has been made following students' abilities proportionally. The questions are made by teachers in charge of Islamic religious education subjects. So that the questions made can be adjusted to the students' abilities. This kind of test is called a teacher-made test. ${ }^{17}$

Fifth, analyze the questions that have been tested based on the test results as evaluation material to prepare the next assessment questions. Sixth, revising the questions that have been tested and making new questions. In the fifth and sixth stages, the benchmark is the assessment that has been done previously, such as daily and mid-semester tests.

These stages align with Zainal Arifin's planning for learning assessments: formulating assessment objectives, identifying competencies and learning outcomes, compiling grids or blueprints, developing instrument drafts, testing, analyzing and revising, and assembling new instruments.

In identifying the questions' competence applied to online-based exams in Islamic religious education learning at the Nahdlatul Ulama 05 Brangsong High School, the questions are still based on the cognitive domain. The online-based exam implemented so far uses an objective test in multiple-choice. The affective and

\footnotetext{
${ }^{16}$ Mujahidin. Interview. IRE Teacher of SMA NU 05 Brangsong. 29 Maret 2021. 10.00 WIB

${ }^{17}$ Naïma Lafrarchi, 'Assessing Islamic Religious Education Curriculum in Flemish Public Secondary Schools', Religions 11, no. 3 (March 2020): 110, https:/ / doi.org/10.3390/rel11030110.
} 
psychomotor aspects assessment has not been covered in online-based exam evaluations. In contrast, the trial was conducted to test the quality of the questions. The subject teachers' questions are directly tested on students in daily tests and midterm exams.

The teacher evaluates the assessment that has been done previously so that the teacher can improve the questions that will be asked next. The planning and implementation are different from what was explained by Zainal Arifin that the questions should be tested first. ${ }^{18}$ Thus, planning the assessment of Islamic religious education learning at the Nahdlatul Ulama 05 Brangsong High School applies authentic assessment and testing questions first. To maintain time efficiency and quality of exams, strategies and teacher innovation are needed to carry out learning more optimally.

The evaluation carried out by the teacher on students must be able to guarantee changes from each evaluation he does. The implementation in each evaluation shows the level of anticipation of the shortcomings and weaknesses during the implementation of learning. Anas Sudijono conveyed that the implementation of learning evaluation can be exemplary if the implementation of the evaluation applies three basic principles: ${ }^{19}(1)$. The comprehensive principle is that evaluation must be carried out as a whole, including aspects of development or behavioral changes that occur in students (2). The principle of continuity, namely evaluation, must be carried out regularly from time to time, (3) The objective principle is that evaluation must be kept away from subjective factors from the teacher and treat students fairly.

The purpose of the evaluation itself is to find out whether students' learning process is following the learning implementation plan that has been implemented. Checking student learning outcomes whether there are deficiencies or not in the learning process, looking for solutions to the shortcomings that students experience, and storing how well students are in the competencies applied. ${ }^{20}$ So why is the role

\footnotetext{
${ }^{18}$ Arifin, Evaluasi pembelajaran, 19.

${ }^{19}$ Anas Sudijono, Pengantar evaluasi pendidikan (Jakarta: PT RajaGrafindo, 2011).

${ }^{20}$ Binh Thai Pham et al., 'Performance Evaluation of Machine Learning Methods for Forest Fire Modeling and Prediction', Symmetry 12, no. 6 (June 2020): 1022, https://doi.org/10.3390/sym12061022; Omid Ghorbanzadeh et al., 'Evaluation of Different Machine Learning Methods and Deep-Learning Convolutional Neural Networks for Landslide Detection', Remote Sensing 11, no. 2 (January 2019): 196, https://doi.org/10.3390/rs11020196.
} 
of learning evaluation so important? Learning evaluation is very important because we have to know whether or not a learning system implemented by educators is effective.

\section{Implementation of Online Assessment on Islamic Religious Education Learning}

Evaluation is one of the essential activities in education. Evaluation provides information about the success of a lesson. With the evaluation will be known the shortcomings and weaknesses of a lesson. ${ }^{21}$ Evaluation is a systematic and continuous process to collect, analyze, and interpret information in determining student achievement of learning objectives based on specific considerations and criteria to make a decision. ${ }^{22}$

The evaluation of the exam on Islamic religious education learning at the Nahdlatul Ulama 05 Brangsong High School was carried out online. So, in its implementation, it must adjust to the needs that have been carried out in planning the learning evaluation.

The online-based exam evaluation conducted at the Nahdlatul Ulama 05 Brangsong High School has several stages. The stages are divided into two types. (1) pre-test stage and (2) examination implementation stage.

The pre-exam in its implementation has several stages, namely, (1) preparation and preparation of schedules, (2) division of test rooms, and (3) installing applications. Making and compiling a schedule is an activity carried out under learning assessment, namely the systematic principle. The assessment carried out in a planned manner is realized by making a schedule to obtain a clear picture. Making the schedule has guidelines when the IRE exam takes place. The schedule will provide direction for action. Distribution of test cards with a username and password used to $\log$ in to the application.

The next pre-test stage is the division of the test room. The division of the test room is related to the wifi capacity used. Where in each class one wifi can accommodate a maximum of 40 cellphones. This stage is because the online-based

\footnotetext{
${ }^{21}$ María Ortiz and Claudia Rubio, Educational Evaluation: 21st Century Issues and Challenges (Nova Science Publishers, 2009).

22 Diana Pereira, Maria Assunção Flores, and Laila Niklasson, 'Assessment Revisited: A Review of Research in Assessment and Evaluation in Higher Education', Assessment \& Evaluation in Higher Education 41, no. 7 (2 October 2016): 1008-32, https:/ / doi.org/10.1080/02602938.2015.1055233.
} 
exam evaluation itself, according to Romli, is an exam system that uses a network in the implementation process. While the online-based exam evaluation at Nahdlatul Ulama 05 Brangsong High School uses a local area network, where the network only covers a small area, namely schools connected between buildings. As for the service using the intranet. Intranet is a small part of the internet that is private and limited internal use. ${ }^{23}$

A connected intranet network that is already connected by a server. Meanwhile, those already connected will not be able to access the browser or anything else unless the server has set the application or site. This exam minimizes students cheating on web pages or exchanging answers with other participants. This application has a feature where students can open the application. Then the function of the button on the cellphone does not work except what is in the application. As stated by Mr. Rifky Abu Zamroh as follows:

"After opening the application, it won't work with the back button, and everything turns off. It can't. To activate and exit the application, there is a unique token from the operator. To complete the test. It's like so that he can get his cellphone back to normal." 24

The next stage is to install the application. The installation of the application is the stage of preparing the media used, where the media used is an application made specifically for online-based exams. There are two applications installed and one is an application for students used for exams, the second is an application for supervisors. The application is used on mobile or computer media. However, specific uses for Android, other than Android, can be accessed with the link provided. There is also data collection for students who do not have a cellphone or cannot be used in the exam. For participants who cannot use mobile phones in the exam, the committee has prepared a computer laboratory as an alternative.

The exam implementation stage is where students use the application to carry out tests by answering questions. There are three stages at the exam implementation stage: logging in, working on questions, and ending the test.

${ }^{23}$ Juli Yanti Harahap, 'Hubungan Antara Kontrol Diri Dengan Ketergantungan Internet Di Pustaka Digital Perpustakaan Daerah Medan', JURNAL EDUKASI: Jurnal Bimbingan Konseling 3, no. 2 (3 July 2017): 131-45, https://doi.org/10.22373/je.v3i2.3091.

${ }^{24}$ M. Rifky Abu Zamroh. Interview. Operator server ujian online. 24 Maret 2021. 10.30 WIB 
The first stage is logging in. At this stage, the process begins by entering the username and password listed on the exam card that has been integrated with the computer server containing the student's data. In connection with this, an operator is in charge of setting the application.

Students do not need to enter personal data because the application already knows the questions and what subjects are being tested for these participants. Students do not need to choose subjects because they have been set on the server computer. This online exam confirms what Ahmaddul Hadi said in his book "Computer Network Administration," which states that an online-based exam system makes it easy for information to be accessed anytime and anywhere, whose networks are connected. ${ }^{25}$ This data integration makes it easier for students because they no longer need to enter personal data and choose questions to be tested. Second, to start working on the test questions, students must first enter the token code given by the supervisor.

The token code will change automatically every 15 minutes, thereby minimizing cheating that occurs to students. You have to ask the exam room supervisor to get a new token code. Furthermore, students can work on the questions under the allotted time. ${ }^{26}$

Each participant's time is the same, and the time will run when the token code is entered. The application contains the remaining time the examinee has to answer the questions. The exam room supervisor can monitor the activity of the examinee through the available supervisor application. So, that the exam room supervisor can know the activities of the examinees.

Third, to complete the exam, you must also enter the token code given by the supervisor. This online exam makes students unable to finish the exam at will. So that students will use their time well because they cannot end the exam before being given a token code to end the exam.

In the subject of Islamic religious education and using an application that the institution has determined, the online-based exam also uses the google form. There

\footnotetext{
${ }^{25}$ Ahmodul Hadi, Administratif Jaringan Komputer (Prenada Media, 2016).

${ }^{26}$ Mulia Rahmayu, Catur Eko Purnomo, and Budi Sudrajat, 'Aplikasi Ujian Online Berbasis Intranet Pada Mata Pelajaran Simulasi Digital Di SMK Yadika 4 Ciledug', Petir 12, no. 2 (6 August 2019): 145-54, https:/ / doi.org/10.33322/ petir.v12i2.473.
} 
are two test models in Islamic Religious Education subjects using the google form. First, students work on test questions. After they finish, students can see the value, and if the score is less or participants are not satisfied, they can repeat until the score is complete or until the desired value is achieved.

However, students cannot see which answers are correct or wrong. In the second model, students, after completing work, can see the results of their scores. Correct and incorrect answers can also be seen. However, if the score is less, the student cannot repeat the answer. The student only knows which answer is wrong and which is correct.

The two test models are based on an explanation from Sutarto Hadi and Jaidun that there are three types of student assessment, namely, summative assessment, formative assessment, and assessment as learning. The assessment applied to Islamic religious education at Nahdlatul Middle School. Ulama 05 Brangsong is included in the third assessment, namely, assessment as learning, where students evaluate themselves. ${ }^{27}$ This statement was corroborated by Daulay, followed by Fitriani Rahayu, who revealed that evaluation in Islamic religious education is not only limited to numbers but more than that how students can evaluate themselves. ${ }^{28}$

Based on the explanation above, in this case, the implementation of onlinebased exams in Islamic religious education learning at the Nahdlatul Ulama 05 Brangsong High School. In addition, following the online exam system set by the institution by using a particular application designed to implement online exams also implements an online-based exam system using services that are already available, namely using Google Forms.

In the planning and implementation, Mr. Mujahidin, S. Pd, revealed "the results of the upload questions, all who work on the network server, there is a separate committee." 29 For Islamic religious education teachers themselves, the first is more accessible from the two online-based exams because the teacher only makes questions according to the requirements. With the template provided, then upload it using the

\footnotetext{
27 Sutarto Hadi Prayitno and Jaedun, 'Authentic Assessment Competence of Building Construction Teachers in Indonesian Vocational Schools', Journal of Technical Education and Training 10, no. 1 (28 June 2018), https://publisher.uthm.edu.my/ojs/index.php/JTET/article/view/2081.

${ }^{28}$ Fitriani Rahayu, 'Konsep Dasar Evaluasi Dalam Pendidikan Islam', Jurnal Ilmiah Iqra' 13, no. 2 (21 October 2019): 1-14, https:// doi.org/10.30984/jii.v13i2.933.

${ }^{29}$ Mujahidin. Interview. IRE Teacher of SMA NU 05 Brangsong
} 
link provided by the committee. As for students, there is not much difference in the implementation of online-based exams that institutions and Islamic religious education teachers apply. It's just that the purpose of the assessment itself is different, as described previously.

Online-based exams conducted by teachers and students should not only be ceremonial but must include educational values. Assessment with affective, psychomotor, and cognitive references is the main focus. ${ }^{30}$ It is not just a mere cognitive assessment but is comprehensive. ${ }^{31}$ The 2013 curriculum is designed to cover this, but teachers still have difficulty implementing this authentic assessment. ${ }^{32}$ Online assessment does have its advantages, but teachers have challenges and drawbacks that make students only focus on cognitive.

The success of learning in the classroom can be seen from the extent to which mastery of competencies that all students have mastered. Student learning outcomes can be expressed in three aspects, commonly referred to as domains or domains, namely cognitive, affective, and psychomotor. ${ }^{33}$ Assessment is done to determine the success of achieving educational goals. In a limited scope, learning assessment is carried out to determine students' level of success. While in broad scope, learning assessment is carried out to determine the success and weakness of a learning process in achieving educational goals that are aspired. ${ }^{34}$

Assessment is a form of evaluation technique that is one of the main parts of a learning process. The assessment results are used as benchmarks for learning objectives as determined in the curriculum have been achieved or not. ${ }^{35}$ Assessment

\footnotetext{
${ }^{30}$ Inayati Huda, 'Implementation of Authentic Assessment in Thematic Learning 2013 Curriculum at Madrasah Ibtidaiyah', Journal of K6 Education and Management 3, no. 4 (25 December 2020): 456-66, https://doi.org/10.11594/jk6em.03.04.05.

${ }^{31}$ Debby Intan Safitri, Mudzanata Mudzanata, and Anggun Dewi Setya Putri, 'The Implementation of Authentic Assessment in Thematic Learning in Elementary Schools', International Journal of Elementary Education 4, no. 2 (23 July 2020): 255-60, https:/ / doi.org/10.23887/ijee.v4i2.25551.

32 Alwen Bentri, Abna Hidayati, and Ulfia Rahmi, 'The Problem Analysis in Applying Instrument of Authentic Assessment in 2013 Curriculum', International Journal of Science and Research (IJSR), 2016, 1008-12.

${ }^{33}$ Rola Ajjawi et al., 'Aligning Assessment with the Needs of Work-Integrated Learning: The Challenges of Authentic Assessment in a Complex Context', Assessment \& Evaluation in Higher Education 45, no. 2 (17 February 2020): 304-16, https:/ / doi.org/10.1080/02602938.2019.1639613.

34 Muhammad Nur Wangid et al., 'The Evaluation of Authentic Assessment Implementation of Curriculum 2013 in Elementary School', Jurnal Penelitian Dan Evaluasi Pendidikan 21, no. 1 (30 June 2017): 104-15, https://doi.org/10.21831/pep.v21i1.15779.

${ }^{35}$ Kay Colthorpe et al., 'Drivers for Authenticity: Student Approaches and Responses to an Authentic Assessment Task', Assessment \& Evaluation in Higher Education 46, no. 7 (3 October 2021): 995-1007, https://doi.org/10.1080/02602938.2020.1845298.
} 
can also be used to assess how far the learning desires have been achieved with the development and changes in the curriculum that apply from time to time.

\section{CONCLUSION}

Planning Evaluation of online-based exams in Islamic Religious Education learning at SMA NU 05 Brangsong is divided into two types, general planning, and special planning. General planning has stages (1) Preparation of school work program at the beginning of the school year related to exams. (2) Formation of the examination committee, (3) Prepare hardware and software equipment. Planning specifically has stages, (1) Determining the purpose of making questions (daily tests, mid-semester assessments, or end-of-semester assessments), (2) Identifying students' abilities in mastering the material, (3) Compiling question grids and question cards, (4) Making questions from the easiest to the hardest proportionally, (5) Analyzing the questions that are tested on students, then being evaluated, (6) Revising the questions that have been tested and making new questions.

The implementation of online-based exam evaluation in Islamic Religious Education learning at SMA NU 05 Brangsong is divided into two stages: the pre-test and the exam. The pre-test stage has stages: 1) Preparation and preparation of test schedules. 2) Division of test rooms. 3) Installing test applications for students and supervisor applications for room supervisors. The exam stage has stages: 1) Students fill in their username and password. 2) Students work on questions by entering a token to start it. 3) Students complete the test and exit the application using the token code given by the supervisor.

\section{REFERENCES}

Ajjawi, Rola, Joanna Tai, Tran Le Huu Nghia, David Boud, Liz Johnson, and CarolJoy Patrick. 'Aligning Assessment with the Needs of Work-Integrated Learning: The Challenges of Authentic Assessment in a Complex Context'. Assessment \& Evaluation in Higher Education 45, no. 2 (17 February 2020): 30416. https://doi.org/10.1080/02602938.2019.1639613.

Aminudin, Nur, and Irwan Susilo. 'Perancangan Sistem Aplikasi Ujian Online Berbasis Web Pada Sma Negeri 1 Kalirejo'. Aisyah Journal Of Informatics and 
Tafkir: Interdisciplinary Journal of Islamic Education

Electrical Engineering (A.J.I.E.E) 1, no. 1 (1 August 2019): 81-88. https://doi.org/10.30604/jti.v1i1.14.

Arifin, Zainal. Evaluasi pembelajaran: prinsip, teknik, dan prosedur. Remaja Rosdakarya, 2009.

Baharun, Hasan. 'Penilaian Berbasis Kelas Pada Pembelajaran Pendidikan Agama Islam Di Madrasah'. MODELING: Jurnal Program Studi PGMI 3, no. 2 (18 September 2016): 204-16.

Balan, Yohanes Adio, Sudarmin, and Kustiono. ‘Pengembangan Model Computer Based Test (CBT) Berbasis Adobe Flash Untuk Sekolah Menengah Kejuruan'. Innovative Journal of Curriculum and Educational Technology 6, no. 1 (2017).

Bentri, Alwen, Abna Hidayati, and Ulfia Rahmi. 'The Problem Analysis in Applying Instrument of Authentic Assessment in 2013 Curriculum'. International Journal of Science and Research (IJSR), 2016, 1008-12.

Braier-Lorimer, Darryl Alexander, and Hannah Warren-Miell. 'A Peer-Led Mock OSCE Improves Student Confidence for Summative OSCE Assessments in a Traditional Medical Course'. Medical Teacher 0, no. 0 (25 November 2021): 1-6. https://doi.org/10.1080/0142159X.2021.2004306.

Colthorpe, Kay, Harrison Gray, Louise Ainscough, and Hardy Ernst. 'Drivers for Authenticity: Student Approaches and Responses to an Authentic Assessment Task'. Assessment E Evaluation in Higher Education 46, no. 7 (3 October 2021): 995-1007. https:// doi.org/10.1080/02602938.2020.1845298.

Creswell, John W. Qualitative Inquiry and Research Design: Choosing Among Five Approaches. SAGE Publications, 2012.

Fadri, Nurul, and Muhammad Khafid. 'Peran Kecerdasan Spiritual Memoderasi Pengaruh Dimensi Fraud Diamond Dan Self-Efficacy Terhadap Kecurangan Akademik'. Economic Education Analysis Journal 7, no. 2 (2018): 430-48.

Fathi, Masood, Dalila Benedita Machado Martins Fontes, Matias Urenda Moris, and Morteza Ghobakhloo. 'Assembly Line Balancing Problem: A Comparative Evaluation of Heuristics and a Computational Assessment of Objectives'. Journal of Modelling in Management 13, no. 2 (1 January 2018): 455-74. https:// doi.org/10.1108/JM2-03-2017-0027. 
Galan, Juanjo. ‘Towards A Relational Model for Emerging Urban Nature Concepts: A Practical Application and an External Assessment in Landscape Planning Education'. Sustainability 12, no. 6 (January 2020): 2465. https://doi.org/10.3390/su12062465.

Ghorbanzadeh, Omid, Thomas Blaschke, Khalil Gholamnia, Sansar Raj Meena, Dirk Tiede, and Jagannath Aryal. 'Evaluation of Different Machine Learning Methods and Deep-Learning Convolutional Neural Networks for Landslide Detection'. Remote Sensing 11, no. 2 (January 2019): 196. https://doi.org/10.3390/rs11020196.

Hadi, Ahmodul. Administratif Jaringan Komputer. Prenada Media, 2016.

Harahap, Juli Yanti. 'Hubungan Antara Kontrol Diri Dengan Ketergantungan Internet Di Pustaka Digital Perpustakaan Daerah Medan'. JURNAL EDUKASI: Jurnal Bimbingan Konseling 3, no. 2 (3 July 2017): 131-45. https://doi.org/10.22373/je.v3i2.3091.

Hidayat, Tatang, and Abas Asyafah. 'Konsep Dasar Evaluasi Dan Implikasinya Dalam Evaluasi Pembelajaran Pendidikan Agama Islam Di Sekolah'. AlTadzkiyyah: Jurnal Pendidikan Islam 10, no. 1 (29 May 2019): 159-81. https://doi.org/10.24042/atjpi.v10i1.3729.

Huda, Inayati. 'Implementation of Authentic Assessment in Thematic Learning 2013 Curriculum at Madrasah Ibtidaiyah'. Journal of K6 Education and Management 3, no. 4 (25 December 2020): 456-66. https:// doi.org/10.11594/jk6em.03.04.05. Kartikasari, Diah Arum. 'Pemahaman Matematika: Penerapan Model Arcs Dan Penilaian Kinerja'. Jurnal Evaluasi Pendidikan 9, no. 1 (30 March 2018): 6-15. https://doi.org/10.21009/JEP.091.02.

Lafrarchi, Naïma. 'Assessing Islamic Religious Education Curriculum in Flemish Public Secondary Schools'. Religions 11, no. 3 (March 2020): 110. https://doi.org/10.3390/rel11030110.

Marfuah, Anis, and Febriza Febriza. 'Penilaian Autentik Pada Pembelajaran Pendidikan Agama Islam (PAI) Di Sekolah Dan Perguruan Tinggi'. FONDATIA 3, no. 2 (30 September 2019): 35-58. https://doi.org/10.36088/fondatia.v3i2.301. 
Miles, Matthew B., A. Michael Huberman, and Johnny Saldana. Qualitative Data Analysis: A Methods Sourcebook. SAGE Publications, 2018.

Ortiz, María, and Claudia Rubio. Educational Evaluation: 21st Century Issues and Challenges. Nova Science Publishers, 2009.

Pereira, Diana, Maria Assunção Flores, and Laila Niklasson. 'Assessment Revisited: A Review of Research in Assessment and Evaluation in Higher Education'. Assessment \& Evaluation in Higher Education 41, no. 7 (2 October 2016): 100832. https:// doi.org/10.1080/02602938.2015.1055233.

Pham, Binh Thai, Abolfazl Jaafari, Mohammadtaghi Avand, Nadhir Al-Ansari, Tran Dinh Du, Hoang Phan Hai Yen, Tran Van Phong, et al. 'Performance Evaluation of Machine Learning Methods for Forest Fire Modeling and Prediction'. Symmetry 12, no. 6 (June 2020): 1022. https://doi.org/10.3390/sym12061022.

Pollitt, Rachel, Caroline Cohrssen, and Wee Tiong Seah. 'Assessing Spatial Reasoning during Play: Educator Observations, Assessment and Curriculum Planning'. Mathematics Education Research Journal 32, no. 2 (1 June 2020): 331-63. https://doi.org/10.1007/s13394-020-00337-8.

Prayitno, Sutarto Hadi, and Jaedun. 'Authentic Assessment Competence of Building Construction Teachers in Indonesian Vocational Schools'. Journal of Technical Education and Training 10, no. 1 (28 June 2018). https://publisher.uthm.edu.my/ojs/index.php/JTET/article/view/2081.

Rahayu, Anita Budi. 'Analisis Presrektif Guru Terhadap Kebutuhan Materi Reading Siswa Kelas XII Sekolah Menengah Kejuruan (SMK) Teknik Otomotif Untuk Menghadapi Ujian Nasional'. Jurnal Riset Teknologi Dan Inovasi Pendidikan (Jartika) 4, no. 1 (5 May 2021): 195-202.

Rahayu, Fitriani. 'Konsep Dasar Evaluasi Dalam Pendidikan Islam'. Jurnal Ilmiah Iqra' 13, no. 2 (21 October 2019): 1-14. https://doi.org/10.30984/jii.v13i2.933.

Rahmayu, Mulia, Catur Eko Purnomo, and Budi Sudrajat. 'Aplikasi Ujian Online Berbasis Intranet Pada Mata Pelajaran Simulasi Digital Di SMK Yadika 4 Ciledug'. Petir 12, no. 2 (6 August 2019): 145-54. https://doi.org/10.33322/petir.v12i2.473. 
Retnawati, Heri. Teori Respon Butir Dan Penerapannya: Untuk Peneliti, Praktisi, Pengukuran Dan Pengujian, Mahasiswa Pascasarjana. Yogyakarta: Parama Publishing, 2014.

Safitri, Debby Intan, Mudzanata Mudzanata, and Anggun Dewi Setya Putri. 'The Implementation of Authentic Assessment in Thematic Learning in Elementary Schools'. International Journal of Elementary Education 4, no. 2 (23 July 2020): 255-60. https://doi.org/10.23887/ijee.v4i2.25551.

Sagita, Nur Nirmala, and Amir Mahmud. 'Peran Self Regulated Learning Dalam Hubungan Motivasi Belajar, Prokrastinasi Dan Kecurangan Akademik'. Economic Education Analysis Journal 8, no. 2 (12 July 2019): 516-32. https://doi.org/10.15294/eeaj.v8i2.31482.

Sudijono, Anas. Pengantar evaluasi pendidikan. Jakarta: PT RajaGrafindo, 2011.

Umami, Muzlikhatun. ‘Penilaian Autentik Pembelajaran Pendidikan Agama Islam Dan Budi Pekerti Dalam Kurikulum 2013'. Jurnal Kependidikan 6, no. 2 (30 November 2018): 222-32. https:// doi.org/10.24090/jk.v6i2.2259.

Wangid, Muhammad Nur, Ali Mustadi, Anwar Senen, and Nur Luthfi Rizqa Herianingtyas. 'The Evaluation of Authentic Assessment Implementation of Curriculum 2013 in Elementary School'. Jurnal Penelitian Dan Evaluasi Pendidikan 21, no. 1 (30 June 2017): 104-15. https://doi.org/10.21831/pep.v21i1.15779. 